\title{
Photoinactivation of Staphylococcus aureus using protoporphyrin IX: the role of haem-regulated transporter HrtA
}

\author{
Joanna Nakonieczna $^{1}$ - Monika Kossakowska-Zwierucho ${ }^{1}$ - Michalina Filipiak ${ }^{1,2}$. \\ Weronika Hewelt-Belka ${ }^{3}$. Mariusz Grinholc ${ }^{1} \cdot$ Krzysztof Piotr Bielawski $^{1}$
}

Received: 7 August 2015 / Revised: 1 November 2015 / Accepted: 4 November 2015 / Published online: 3 December 2015

(C) The Author(s) 2015. This article is published with open access at Springerlink.com

\begin{abstract}
Light- and photosensitiser-based antimicrobial photodynamic therapy is a very promising approach to the control of microbial infections. How the phenotypic features of a microorganism affect its response to photosensitiserbased photokilling represents an area of substantial research interest. To understand the mechanisms governing the phenomenon of a strain-dependent response to photodynamic inactivation (PDI), we analysed the possible role of the membrane-located haem transporter HrtA in Staphylococcus aureus. We used a $S$. aureus strains with an inactivated component of the haem-regulated transporter, HrtA, along with its wild-type counterpart to determine differences in PDI outcome and photosensitiser uptake between the studied isogenic strains. We observed that a lack of HrtA protein potentiates the phototoxic effect towards $S$. aureus but only when extracellular protoporphyrin IX is used. The observed effect may depend on the function of the HrtA transporter but is likely to result from changed membrane properties following the absence of the protein in the membrane. This indicates that disturbing the membrane properties is an attractive method
\end{abstract}

Electronic supplementary material The online version of this article (doi:10.1007/s00253-015-7145-5) contains supplementary material, which is available to authorized users.

Joanna Nakonieczna

joanna.nakonieczna@biotech.ug.edu.pl

1 Intercollegiate Faculty of Biotechnology, University of Gdansk and Medical University of Gdansk, Kladki 24, 80-822 Gdansk, Poland

2 Present address: Faculty of Biology, University of Gdansk, Wita Stwosza 59, 80-308 Gdansk, Poland

3 Faculty of Chemistry, Gdansk University of Technology, Gabriela Narutowicza 11/12, Gdansk, Poland for improving the efficacy of the photodynamic inactivation of microorganisms.

Keywords Protoporphyrin IX · Photoinactivation ·

Membrane fluidity $\cdot$ Lipid content $\cdot$ Staphylococcus aureus

\section{Introduction}

Photodynamic inactivation of bacterial pathogens is becoming an interesting therapeutic option to treat microbial infections; however, this method can also be utilised in food decontamination (Tortik et al. 2014) and environmental applications (Almeida et al. 2014). Previously, the method has primarily been used in cancer treatments, especially in countries in which it was clinically approved in the late 1980s (Prout et al. 1987). Soon thereafter, both Gram-positive and Gram-negative bacteria were found to be killed using this method, and antimicrobial photodynamic chemotherapy was developed (Merchat et al. 1996; Wilson et al. 1995). The related photodynamic action is caused by three elements, namely light, a photosensitiser and oxygen. A photosensitiser, which is usually a small molecular compound, accumulates in microbial cells and, upon illumination with light of an appropriate wavelength, becomes excited into its triplet state. The energy produced during excitation is transmitted from a photosensitiser via electron transfer to either (1) cellular substrate and then to oxygen to form several reactive oxygen species (type I mechanism) or (2) transferred directly to molecular oxygen to form a very reactive singlet oxygen (type II mechanism), which is primarily responsible for phototoxic damage in target cells. Various biomolecules are affected by the photodynamic action, namely proteins (e.g. aromatic amino acids), nucleic acids and unsaturated lipids, depending on the nature of the photosensitiser (charge and polarity) and its subcellular localisation (Ochsner 1997). Effective 
photosensitisers, i.e. those that cause a significant (at least 4$\log$ ) decrease in cell survival, are believed to localise in the cell membrane and express cytotoxic effects towards membrane components (Ooi et al. 2009; Oriel and Nitzan 2012). This is the mechanism by which porphyrin-based photosensitisers are believed to act (Ooi et al. 2009). The effectiveness of photodynamic inactivation (PDI) treatment is generally independent of the antimicrobial resistance pattern; thus, multiresistant bacteria, such as methicillin-resistant $S$. aureus, can be eradicated with photodynamic treatment with efficiency similar to its methicillin-sensitive counterpart (Maisch et al. 2007; Schastak et al. 2010). The singlet oxygen and other reactive oxygen species-based mechanisms (highly reactive free radicals) of photodynamic action assume that the development of resistance to such treatments is highly unlikely (Giuliani et al. 2010; Tavares et al. 2010). From a clinical point of view, the development of effective therapeutic treatments that do not induce resistance is of high interest, particularly in cases when the treatment must be performed several times.

Thus far, it has not been demonstrated that resistance to photodynamic inactivation can be induced even with low doses of light. However, we observed that clinical isolates of the same species present significantly different phenotypic variations in response to porphyrin-based photodynamic treatment. The observed differences ranged from a $0.2 \log _{10}$ reduction of colony-forming unit (CFU) per millilitre, representing strains with elevated resistance to PDI, to a 5 $\log _{10}$ reduction of CFU per millilitre in vulnerable strains. Several attempts were undertaken to elucidate the mechanism responsible for this phenomenon; however, only biofilm production was shown to significantly affect the effectiveness of the photodynamic process (Grinholc et al. 2008). Biofilm production, however, is not the only factor contributing to these differences in survival upon photodynamic treatment; in the group of weak biofilm producers, Staphylococcus aureus strains with elevated resistance to PDI were also observed. Several other factors can potentially contribute to a particular response of the strain to photodynamic treatment. The activity of enzymes that detoxify reactive oxygen species, which arise as a consequence of PDI treatment, can be a contributing factor. However, superoxide dismutases, which inactivate superoxide anions, have been shown to have only secondary effects on PDI outcome (Nakonieczna et al. 2010).

Currently, little is known about the mechanism by which bacterial cells accumulate exogenous porphyrins. The haem transport system is suggested to play a crucial role in this process (Moriwaki et al. 2011). Different metalloporphyrins are recognised by a well-characterised staphylococcal ironregulated surface determinant system (Isd), namely the IsdH haem receptor, and then transferred to IsdA. This indicates that the Isd system may be used by these antibacterial compounds to access the interior of the cells (Moriwaki et al. 2011). The IsdC protein was also demonstrated to predominantly bind to protoporphyrin IX (PpIX) and to haem to a lesser extent (Mack et al. 2004). Another system that is involved in haem import in $S$. aureus cells is the membranelocalised ATP-binding cassette (ABC) transporter HtsA (Skaar et al. 2004). however, this particular import system is more engaged in staphyloferrin A transport (Beasley et al. 2009). Notably, S. aureus is very sensitive to haem and possesses systems that can alleviate the toxicity of this compound. HrtA and HrtB are two cooperating proteins that protect bacterial cells from the negative effects of haem accumulation (Torres et al. 2007). Based on literature data, HrtAB is an $\mathrm{ABC}$ transporter, where HrtA acts as ATPase and HrtB is an integral membrane permease forming a substrate transport channel (Stauff et al. 2008). HrtA is upregulated in bacterial cells upon haem presence; however, currently, there are no published data on steady state level of HrtA protein in cells (Friedman et al. 2006). The process of HrtA production is regulated by haem sensor system HssRS, which activates HrtAB (Stauff et al. 2007).

Based on the published data indicating that haem transporters may have a role in porphyrin transport, we investigated the possible role of these transporters in the accumulation of protoporphyrin IX and the potential of photodynamic killing of $S$. aureus. We showed that $S$. aureus mutant lacking HrtA haem transport system accumulated the largest amount of PpIX and was the most vulnerable to photodynamic treatment. However, the observed phenomenon was not dependent on the function of the protein but rather on secondary effects related to its physical absence in the membrane. This indicates that membrane perturbations may improve the efficacy of photodynamic killing via PpIX and potentially other photosensitisers that interact with the bacterial membrane.

\section{Materials and methods}

\section{Bacterial strains and culture media}

This study was conducted with four $S$. aureus strains: (i) S. aureus Newman NCTC 8178 clinical isolate, a wild-type strain (Duthie and Lorenz 1952). (ii) the $S$. aureus $\Delta \mathrm{IsdD}$ isd::erm strain, in which the gene responsible for haem import was replaced with a resistance cassette to erythromycin (Mazmanian et al. 2003). (iii) S. aureus $\Delta$ HtsA, which was obtained via allelic replacement (Mason and Skaar 2009). and (iv) S. aureus $\Delta$ HrtA, which was obtained via allelic replacement (Torres et al. 2007). All of the bacterial strains were provided by Dr. Eric P. Skaar from the Department of Microbiology and Immunology at the Vanderbilt University Medical Center. The bacteria were grown in tryptic soy broth (TSB) (Biomerieux, Marcy l'Etoile, France). To prepare 
divalent metal ion-free medium, TSB was treated with a Chelex ${ }^{\circledR}-100$ chelating ion exchange resin for $6 \mathrm{~h}$ and supplemented with $400 \mu \mathrm{M} \mathrm{MgSO}$. When necessary, Chelextreated TSB medium was supplemented with $\mathrm{FeSO}_{4}$ to a final concentration of $20 \mu \mathrm{M}$. The $S$. aureus $\Delta \mathrm{IsdD}$ strain was cultured in the presence of $10 \mu \mathrm{g}$ erythromycin $\mathrm{ml}^{-1}$ (Fluka, Buchs, Switzerland).

\section{Chemicals}

PpIX was purchased from Sigma-Aldrich ${ }^{\mathrm{TM}} ; 1 \mathrm{mM}$ solution was prepared in dimethyl sulfoxide (DMSO) and stored in the dark at room temperature. 5-Aminolevulinic acid hydrochloride (5-ALA) was purchased from Fluka, Switzerland; a $100 \mathrm{mM}$ solution was prepared in phosphate-buffered saline (PBS), $\mathrm{pH} 6.5$, and kept at $4{ }^{\circ} \mathrm{C}$ for at most 1 week. A new methylene blue (Sigma-Aldrich ${ }^{\mathrm{TM}}$, Munich, Germany) $10 \mathrm{mM}$ solution was prepared in deionised water and stored at $-20{ }^{\circ} \mathrm{C}$. All solvents and other chemicals were of analytical grade, with the exception of those used for experiments with liquid chromatography-mass spectrometry (LC-MS), in which high-performance liquid chromatography (HPLC) and LC-MS grade solvents were used.

\section{Photosensitiser accumulation}

S. aureus strains were grown overnight and adjusted to optical density $(\mathrm{OD})_{600}=0.3$. Protoporphyrin IX was added to $800-\mu \mathrm{l}$ bacterial aliquots to final concentrations in the range of 1-20 $\mu \mathrm{M}$ (for PpIX) and 30-300 $\mu \mathrm{M}$ (for new methylene blue (NMB)). Samples were incubated for $30 \mathrm{~min}$ at $20{ }^{\circ} \mathrm{C}$ in darkness. This temperature was used to assure optimal functioning of the HrtA protein (Stauff et al. 2008). After incubation, the bacterial cells were washed twice with PBS and bacterial cell lysates were prepared by incubating cells in a $0.1 \mathrm{M} \mathrm{NaOH} / 1 \%$ sodium dodecyl sulfate (SDS) $(w / v)$ solution for $24 \mathrm{~h}$ at room temperature. The fluorescence intensity of $100 \mu \mathrm{l}$ of each sample was measured spectrophotometrically with the use of a Victor ${ }^{\mathrm{TM}}$ Multilabel Plate Reader (PerkinElmer, Boston, MA, USA). The PpIX concentration was obtained from a calibration curve that was prepared based on a known concentration of PpIX in a $1 \mathrm{M} \mathrm{NaOH} / 1 \%$ SDS $(w / v)$ solution. In the experiments with trypsin pre-treatment, cells were grown overnight and adjusted to $\mathrm{OD}_{600}=0.3$ and $800-\mu \mathrm{l}$ bacterial aliquots were centrifuged $(1 \mathrm{~min}, 7500 \times \mathrm{g})$ and further dissolved in the same volume of $0.005 \%(w / v)$ concentration of the trypsin. Following incubation with trypsin for $15 \mathrm{~min}, 37{ }^{\circ} \mathrm{C}$, cells were centrifuged $(2 \mathrm{~min}, 7500 \times \mathrm{g})$ and washed twice with PBS. Samples were incubated with PpIX for $30 \mathrm{~min}$ at $37{ }^{\circ} \mathrm{C}$ in darkness and twice washed with PBS. The cells were then subjected to lysis and measurements as described above. Uptake values were presented as PpIX molecules accumulated per cell according to the following formula:

PpIX molecules accumulated per cell

$$
=\frac{\mathrm{PpIX}}{\mathrm{MwPpIX}} \times \mathrm{NA} / \mathrm{CFU}
$$

where PpIX is the amount of molecules obtained from a calibration curve based on known concentrations of PpIX, Mw PpIX is the molecular weight of PpIX (562.6 g/mol), NA is the Avogadro's number $\left(6.022 \times 10^{23}\right)$, and CFU is the colony-forming unit obtained using serial dilutions counted for $1 \mathrm{ml}$ of the analysed samples.

\section{Photoinactivation experiments}

S. aureus strains were grown overnight and adjusted to $\mathrm{OD}_{600}=0.055-0.06$. A specific photosensitiser was added to $800-\mu 1$ aliquots of each bacterial strain to a final concentration of 0-50 $\mu \mathrm{M}$ (PpIX) or $20 \mu \mathrm{M}$ (NMB). Samples were incubated in the dark at $37{ }^{\circ} \mathrm{C}$ for $30 \mathrm{~min}$. Then, $100 \mu \mathrm{l}$ of each sample was transferred into a 96-well plate and illuminated with a specific dose of light. Bacterial survival after photoinactivation was estimated by plating serially diluted bacterial suspensions on tryptic soy agar (TSA) plates. CFUs were counted, and the survival fraction was calculated as a percentage of the surviving bacteria with respect to the surviving bacteria in the untreated sample and presented in decimal logarithmic scale. The results of each experiment are presented as the mean of at least three independent replicates with the standard deviation of the mean.

\section{Illumination method}

Both red and blue light were used in photoinactivation experiments with PpIX. Red light was applied for illumination protocol with NMB as a photosensitiser. Blue light was used in the experiments with 5-ALA treatment. The light (blue light, 385-480 nm, and red incoherent polarised light, 620 $780 \mathrm{~nm}$ ) was generated using a Q.Light PDT lamp (Q Products AG, Rorschach, Switzerland) with changeable filters (www.qlight.info). The lamp delivers a power of $70 \mathrm{~mW} /$ $\mathrm{cm}^{2}\left(4.2 \mathrm{~J} / \mathrm{cm}^{2} / \mathrm{min}\right)$ at a maximum treatment distance of 16 . $5 \mathrm{~cm}$ with a treatment diameter of $16.5 \mathrm{~cm}$ and depth of penetration of 3-4 mm. Bacteria were illuminated in a 96well plate in aliquots of $100 \mu \mathrm{l}$. Light doses ranging from 0 to $500 \mathrm{~J} / \mathrm{cm}^{2}$ were obtained using the red filter, whereas doses that ranged from 0 to $300 \mathrm{~J} / \mathrm{cm}^{2}$ were obtained using the blue filter. During illumination, the temperature of bacterial suspensions did not exceed $37^{\circ} \mathrm{C}$. After illumination, $10 \mu \mathrm{l}$ of bacteria treated with a particular dose of light were collected for serial dilutions and plating. 


\section{Induction of porphyrin production with 5-ALA}

Overnight cultures of $S$. aureus were refreshed in TSB medium to $\mathrm{OD}_{600}=0.1$. The cells were grown with aeration until they reached $\mathrm{OD}_{600}=0.4$. The cultures were divided into five batches of $15 \mathrm{ml}$ each and centrifuged for $10 \mathrm{~min}$ at $4000 \mathrm{rpm}$ at $8{ }^{\circ} \mathrm{C}$. After washing with PBS, the bacteria were resuspended in $10 \mathrm{ml}$ of PBS and 5-ALA was added to final concentrations of $0.01,0.05,0.5$ and $1 \mathrm{mM}$. The bacteria were placed in a shaking incubator $(100 \mathrm{rpm})$ at $37{ }^{\circ} \mathrm{C}$ for $4 \mathrm{~h}$ in the dark. Subsequently, $100-\mu 1$ aliquots were collected and photoinactivation was performed according as previously described (photoinactivation experiments). In these experiments, blue light $\left(50 \mathrm{~J} / \mathrm{cm}^{2}\right.$ light dose) was used. We chose the blue light in our experimental setup with ALA-PDI as originally this type of light was the most extensively studied and finally approved for treatment of acne in USA. Besides, the wavelength in the range of blue light covers the Soret band of PpIX absorption, which is the highest absorption peak within PpIX whole emission spectrum. Bacterial survival after photoinactivation was estimated by plating. The survival rate was presented using a decimal logarithmic scale according to each given concentration of 5-ALA. After incubation with 5ALA, endogenously produced porphyrins were extracted from the bacteria using an $\mathrm{NH}_{4} \mathrm{OH}$ :acetone solution $(1: 9 v / v)$. The bacteria were centrifuged for $5 \mathrm{~min}$ at $4000 \mathrm{rpm}$ at $4{ }^{\circ} \mathrm{C}$, washed with PBS and resuspended in $300 \mu \mathrm{l}$ of an $\mathrm{NH}_{4} \mathrm{OH}$ :acetone $(1: 9 v / v)$ solution. The samples were vigorously shaken for $2 \mathrm{~min}$. Bacterial cell extracts were centrifuged for $5 \mathrm{~min}$ at $9000 \mathrm{rpm}$ at room temperature. The fluorescence of the extracted porphyrins in the supernatants was measured using a Victor ${ }^{\mathrm{TM}}$ Multilabel Plate Reader (PerkinElmer, Boston, MA, USA). The concentration of intracellular porphyrins was estimated based on the calibration curve prepared from the known concentrations of protoporphyrin IX in a solution of $\mathrm{NH}_{4} \mathrm{OH}$ acetone. The porphyrin amount was presented as the concentration $(\mathrm{nM})$ per number of cells, which were estimated by plating. Three independent biological replicates were conducted.

\section{Fluorescence-activated cell sorting analysis}

Fluorescence-activated cell sorting (FACS) was used to detect the increased production of endogenous porphyrins in living cells (Nitzan and Kauffman 1999). Bacteria incubated with 5ALA, as described in the previous section, were collected in aliquots of $25 \mu \mathrm{l}$ and washed with PBS containing $1 \%$ BSA $(w / v)$. Finally, 1-ml samples were analysed on a flow cytometer (Becton Dickinson, Franklin Lakes, NJ, USA). Fluorescence emission was excited with a 488-nm laser light. The fluorescence signal of 5-ALA-treated cells is presented with respect to non-ALA-treated samples. The percentage of fluorescent cells corresponds to the fraction of cells with increased porphyrins produced upon 5-ALA induction with respect to the control cells, which were not incubated with 5-ALA.

\section{Cell membrane fluidity assay}

Temperature-dependent membrane fluidity was quantified by measuring the fluorescence anisotropy with a 1.6-diphenyl1.3.5-hexatriane (DPH) probe (Sigma-Aldrich ${ }^{\mathrm{TM}}$, Munich, Germany), according to modified protocols described by Bayer and Voss (Bayer et al. 2000; Voss and Montville 2014). A 2-mM stock solution of DPH was prepared in tetrahydrofuran, and $4 \mu \mathrm{M}$ working solution was prepared by adding $100 \mu \mathrm{l}$ to $50 \mathrm{ml}$ of $0.05 \mathrm{M}$ Tris- $\mathrm{HCl}(\mathrm{pH} 7.6)$. Residual tetrahydrofuran was removed via gentle flushing with nitrogen. The solution was stored in the dark at $4{ }^{\circ} \mathrm{C}$ until use. Whole-cell suspensions of each bacterial strain were prepared with a bacterial density of $4.5 \mathrm{McF}$ arland units $\left(10^{8} \mathrm{CFU} / \mathrm{ml}\right)$ in TSB medium. Suspensions were pelleted via centrifugation $(5000 \times g, 15 \mathrm{~min})$ and then resuspended in $500 \mu \mathrm{l}$ of digestion buffer $(20 \%[w / v]$ sucrose, 0.05 Tris- $-\mathrm{HCl}$ and $0.145 \mathrm{M} \mathrm{NaCl}[\mathrm{pH} 7.6])$. The bacterial cell wall was then digested with $0.8 \mathrm{U}$ of lysostaphin (A\&A Biotechnology, Gdynia, Poland) in the presence of $6 \mathrm{U}$ of DNAse I (EURx, Gdansk, Poland) for $1 \mathrm{~h}$ at $37^{\circ} \mathrm{C}$. Protoplasts were collected via centrifugation $(9000 \times \mathrm{g}, 15 \mathrm{~min})$ and resuspended in $200 \mu \mathrm{l}$ of fresh digestion buffer. The adequacy of cell wall digestion was confirmed via Gram staining. For DPH labelling, protoplasts suspended in digestion buffer were mixed with DPH solution at a 1:1 ratio to obtain a $2 \mu \mathrm{M}$ final concentration and incubated in the dark at $30{ }^{\circ} \mathrm{C}$ for $45 \mathrm{~min}$. A JASCO Spectrofluorimeter FP-8500 (Japan) was used for fluorescence anisotropy measurements. The analysis was carried out with a $300 \mu \mathrm{l}$ volume of a labelled cell suspension agitated at $200 \mathrm{rpm}$ in a temperature gradient ranging from 20 to $40{ }^{\circ} \mathrm{C}$ (ramping rate $1{ }^{\circ} \mathrm{C}$ per $1 \mathrm{~min}$ ). Above this temperature, a disruption of labelled protoplasts was observed using fluorescence microscopy. The measurement parameters included a vertically polarised excitation wavelength of $360 \mathrm{~nm}$ (bandwidth $5 \mathrm{~nm}$ ) and emission wavelength of $426 \mathrm{~nm}$ (bandwidth $10 \mathrm{~nm}$ ) through a rotating polariser. The signal was measured for $2 \mathrm{~s}$ at each $2.5^{\circ} \mathrm{C}$ interval. Each experiment was performed in three independent biological replicates. Fluorescence anisotropy $(r)$ was calculated according to the following equation:

$r=\frac{I_{v}-I_{p}}{I_{v}+2 I_{p}}$,

where $I_{v}$ and $I_{p}$ represent the fluorescence intensity measured with parallel and perpendicular orientations of the analyser, respectively. 


\section{Lipid fingerprinting using liquid chromatography and quadrupole time-of-flight mass spectrometry}

Samples and bacterial growth conditions were used as previously described (Hewelt-Belka et al. 2014). Bacteria were cultured in $50-\mathrm{ml}$ bovine heart infusion (BHI) medium (BioMerieux, Marcy l'Etoile, France) for $23 \mathrm{~h}$ in $37{ }^{\circ} \mathrm{C}$. The cells were harvested via centrifugation $\left(5 \mathrm{~min}, 7000 \times \mathrm{g}, 20^{\circ} \mathrm{C}\right)$, washed twice with $0.78 \% \mathrm{NaCl}$ and further lyophilised for $23 \mathrm{~h}$. Of lyophilised cells, $15 \mathrm{mg}$ was dissolved in $500 \mu \mathrm{l}$ of deionised water, and extraction was performed in borosilicate glass tubes according to the modified Bligh and Dyer method (Bligh and Dyer 1959). Briefly, $1.9 \mathrm{ml}$ of chloroform:methanol mixture $(1: 2 v / v)$ and $600 \mathrm{mg}$ of glass beads $(0.10-0.11 \mathrm{~mm}$ diameter; Sartorius, Goettingen, Germany) were added to bacterial cells. The mixture was then vortexed $(5 \mathrm{~min})$. Next, $625 \mu \mathrm{l}$ of chloroform was introduced, followed by $10 \mathrm{~s}$ vortexing and the addition of $625 \mu \mathrm{l}$ of deionised water and another $60 \mathrm{~s}$ of vortexing. Afterwards, the sample was centrifuged at $5000 \times \mathrm{g}$ for $10 \mathrm{~min}$ to remove the delipidated cells that remained. The lower organic phase containing lipids was gently aspirated by a glass Pasteur pipette and transferred to a clean glass tube and subsequently analysed via liquid chromatography and quadrupole time-of-flight mass spectrometry (LCQ-TOF-MS). All of the chemicals used were of HPLC and MS grade. Six $S$. aureus HrtA and six S. aureus Newman culture samples were prepared and processed with the same analytical procedure. Samples were analysed on an Agilent 1290 LC system coupled to a 6540 Q-TOF-MS with a dual ESI source (Agilent Technologies, Santa Clara, CA, USA). The data analysis was performed using MassHunter Workstation Software Qualitative Analysis, version B.03.01 (Agilent Technologies, Santa Clara, CA, USA) and Microsoft Excel 2010 (Microsoft, Redmond, USA) according to a previously described method (HeweltBelka et al. 2014).

\section{Statistical analysis}

Each experiment was performed at least in triplicate. The primary data are presented as the means with standard deviations of the mean. The statistical analysis was performed using a one-way analysis of variance (ANOVA) with Tukey's post hoc test. The hypotheses were tested at a significance level of 0.05 . All analyses were performed using the STATISTICA version 10.0 software (StatSoft Inc. 2011, data analysis software system, Tulsa, OK, USA).

\section{Results}

\section{PDI survival assays}

In the first set of experiments, we applied the photodynamic inactivation of wild-type strain Newman and its three isogenic mutants, $\Delta$ HrtA, $\Delta$ HtsA and IsdD, to assess possible differences in vulnerability to PDI. We used PpIX, which is a structural analogue of haem and acts as a photosensitiser. We used monochromatic polarised red light $(623 \pm 23 \mathrm{~nm}, 98 \%$ polarisation) and PpIX concentrations in the range of 0 $50 \mu \mathrm{M}$. The total light dose used was $12 \mathrm{~J} / \mathrm{cm}^{2}$. The reason for using small doses of light in this experiment was to maintain sublethal conditions to assure the viability of bacteria and thus the sufficient expression of the proteins of interest. The experiments were performed either in the presence or absence of iron ions; certain iron-haem transporters are produced in response to a limited amount of $\mathrm{Fe}^{++}$(Mazmanian et al. 2003). The mortality of all of the studied strains was lower in the absence of $\mathrm{Fe}^{++}$(Fig. 1). Reductions in survival at 0.38 , $0.64,0.39$ and $0.57 \log _{10}$ were observed for $\Delta \mathrm{isdD}, \Delta \mathrm{HrtA}$, $\Delta$ HtsA and the wild-type Newman strain, respectively. When $\mathrm{Fe}^{++}$was present in the culture medium, the cells of the Newman strain, $\Delta$ HrtA and $\Delta$ HtsA were killed more efficiently $\left(0.65,1.13\right.$ and $0.57 \log _{10}$ units of survival reduction, respectively), whereas in the case of $\Delta$ isdD, the cell viability remained unchanged. The largest difference in the rate of cell death with respect to the presence of $\mathrm{Fe}^{++}$was observed for the $\Delta$ HrtA strain, where in the presence of iron ions, the viability of the cells was reduced twofold compared with cells in the non- $\mathrm{Fe}^{++}$containing medium $(0.64$ vs. $1.13 \log _{10}$ units of survival reduction). We also performed PpIX uptake studies with respect to the presence of $\mathrm{Fe}^{++}$and did not observe a difference between these two conditions. In summary, $\Delta$ HrtA was the most PDIsusceptible strain in both the presence and absence of $\mathrm{Fe}^{++}$(Fig. 1). Moreover, the observed effect was not related to strain-dependent differences in growth rate in the presence and absence of $\mathrm{Fe}^{++}$. The growth rate of each of the studied strains was reduced to the same extent in the absence of $\mathrm{Fe}^{++}$(on the Supplementary material Fig. S2).

\section{Light-dependent PDI survival}

To characterise the photoinactivation process of the studied strains, we applied PDI survival assays with increasing light doses. Here, we used photoinactivation conditions, in which bacteriocidal effects could be obtained. We were interested if the applied lethal conditions similarly affect the analysed strains. We observed a light dose-dependent response to the treatment in the range of $0-500 \mathrm{~J} / \mathrm{cm}^{2}$ for the red light and 0 $250 \mathrm{~J} / \mathrm{cm}^{2}$ for the blue light. Here, a halogen lamp was used with filters generating a narrow band of blue or red light 

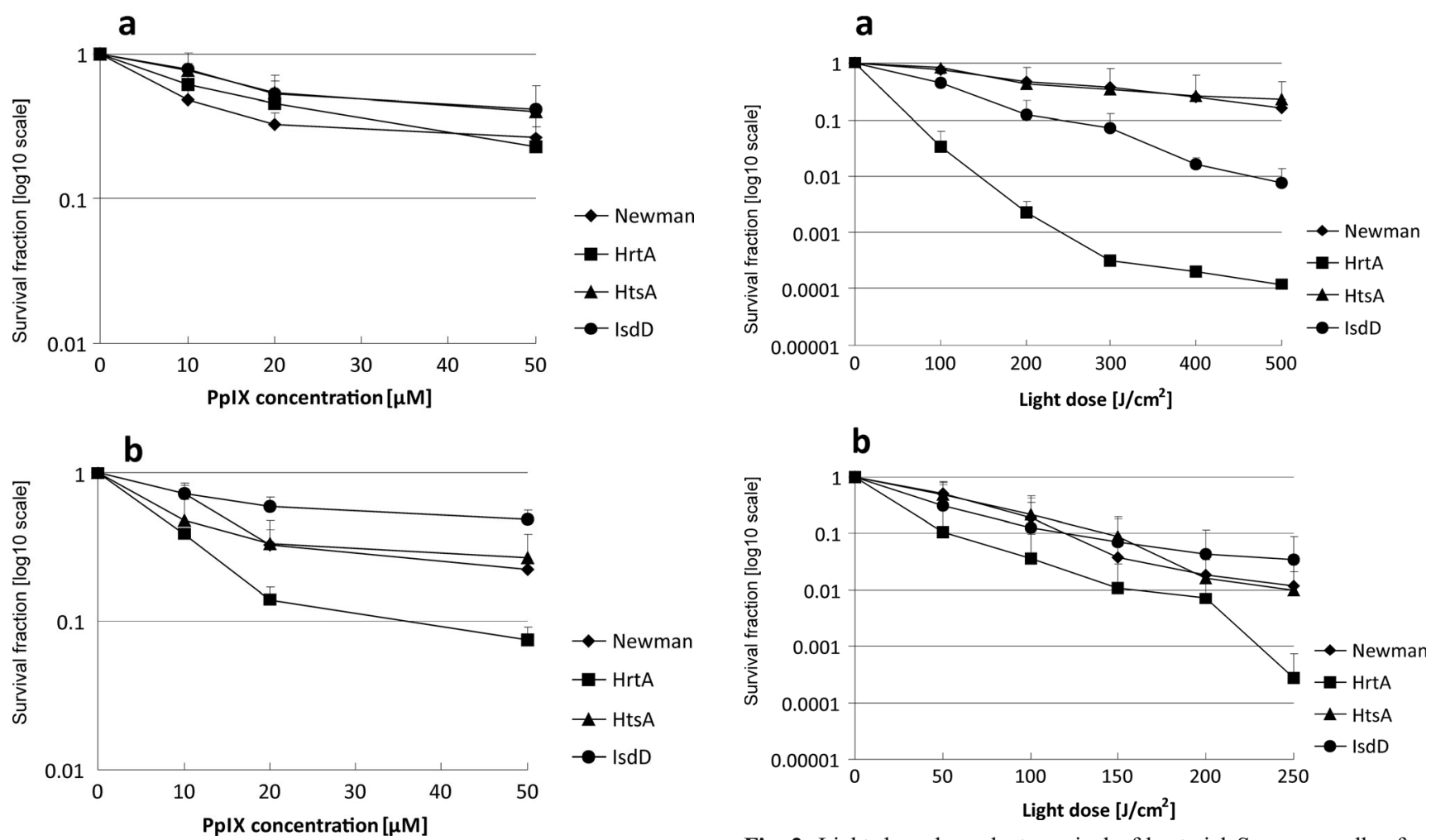

Fig. 1 Survival of bacterial $S$. aureus cells after photodynamic treatment in the absence or presence of $\mathrm{Fe}^{++}$. Bacterial cells were cultured either in medium without iron ions (a) or containing iron ions (b). Cells were incubated with increasing concentrations of PpIX and illuminated with a $12 \mathrm{~J} / \mathrm{cm}^{2}$ light dose $(623 \mathrm{~nm})$. Bacterial survival was measured by serially diluting cells and counting colony-forming units (CFUs) plated on agar plates before and after treatment. The survival fraction was expressed as the number of CFU obtained after PDI treatment with respect to the number of CFU of non-lighttreated cells. The names of the $S$. aureus strains are indicated in the legend

("Materials and methods" section). Both applied wavelengths refer to characteristic spectral properties of porphyrins, in which $Q$ and Sorret bands of absorption spectra are distributed along the entire range of visible light. In each light dosedependent experiment, we applied a $20 \mu \mathrm{M}$ concentration of PpIX. Samples of the treated cells were taken at time intervals that corresponded to a particular light dose (Fig. 2). Again, the $\Delta$ HrtA clearly presented the most PDI-sensitive phenotype. The observed reduction in survival was $4 \log _{10}$ units in viability, whereas in the wild-type Newman strain as well as in $\Delta$ HtsA strain, the observed reduction in survival was estimated to be less than $1 \log _{10}$ unit. For $\Delta \mathrm{IsdD}$, the observed reduction in survival was $2 \log _{10}$ units. When the blue light was applied, $\Delta$ HrtA again appeared to be the most susceptible strain to the treatment. This time, however, the differences in survival rates between the most vulnerable strain $(\Delta \mathrm{HrtA}, 3.5$ $\log _{10}$ units) and the remaining strains $\left(1.5 \log _{10}\right.$ units for $\Delta$ IsdD and $2 \log _{10}$ units for $\Delta$ HtsA and Newman) were not as significant as in the case of the red light treatment. We

Fig. 2 Light dose-dependent survival of bacterial $S$. aureus cells after photodynamic treatment. Survival of the wild-type Newman strain and its three isogenic mutants, $\Delta \mathrm{HrtA}, \Delta \mathrm{HtsA}$ and $\Delta \mathrm{IsdD}$, were measured after PDI treatment with respect to increasing light doses. After incubation with $20 \mu \mathrm{M}$ PpIX, the analysed strains were subjected either to 620 780 (a) or $385-480 \mathrm{~nm}$ (b) narrowband light. Bacterial survival of bacteria was measured by serially diluting cells and counting the CFUs plated on agar plates before and after treatment. The survival fraction is expressed as the number of CFU obtained after PDI treatment with respect to the number of CFU of non-light-treated cells. The names of the $S$. aureus strains are indicated in the legend

believe that it may be the result of the light penetration. The experiments with both types of light were performed in similar technical conditions, in 96-well plates. Red light penetrates deeper, and thus, the chances are bigger to reach also these bacterial cells that are located near the bottom of the flask. Next, we determined whether the decreased survival of $\Delta$ HrtA with respect to reference Newman strain correlated with the photosensitiser (PS) accumulation in mutant and wild-type cells. A significantly greater number of PpIX molecules were accumulated in $\Delta$ HrtA cells than Newman cells (Fig. 3a). Although the trend was observed within all the concentrations tested (1-20 $\mu \mathrm{M}$ PpIX), statistically significant difference was only found for the situation when cells were incubated with $20 \mu \mathrm{M}$ PpIX (Fig. 3a). We also determined whether there were any differences in the accumulation of new methylene blue between the two strains. New methylene blue represents a heterocyclic aromatic chemical compound that differs from the tetrapyrrole structure of porphyrins. In this case, no difference in molecule accumulation was observed between the two 
a

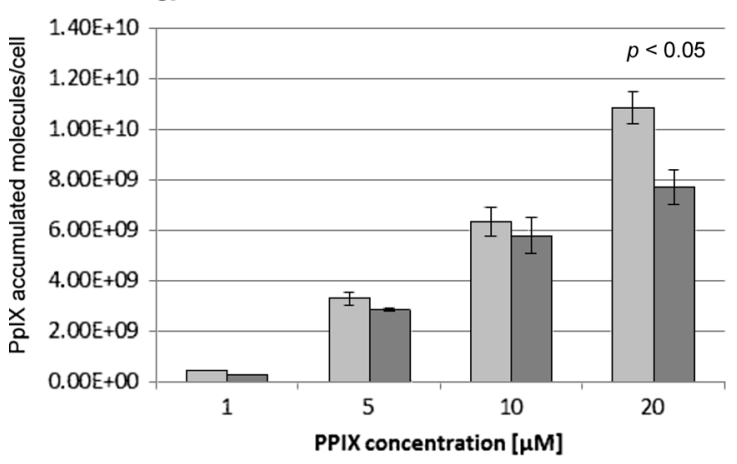

Fig. 3 Protoporphyrin IX and new methylene blue accumulation. Uptake of two photosensitisers, namely PpIX (a) and new methylene blue (b), was studied using the reference $S$. aureus Newman strain and the $S$. aureus HrtA mutant. PS uptake was carried out in the presence of

strains studied (Fig. 3b). A detailed analysis of the survival of $\Delta$ HrtA cells and wild-type Newman cells after NMB-based photodynamic inactivation revealed no differences in the number of surviving cells (Fig. 4).

\section{ALA-induced endogenous photosensitiser production in cells}

Results of the photoinactivation and accumulation studies revealed that the $\Delta$ HrtA mutant had the most pronounced effect of photoinactivation when using exogenously added PpIX. To determine whether endogenously produced porphyrin-based photosensitisers impact PDI response in the studied wildtype Newman strain and the haem transporter mutant $\triangle \mathrm{HrtA}$, the cells were incubated with 5-ALA at concentrations of $0,0.05,0.1$ and $1 \mathrm{mM}$. The 5-ALA compound is a precursor of porphyrin, which is known to cross the bacterial cell wall and induce endogenous porphyrin production (Kennedy and Pottier 1992). Endogenous porphyrins were extracted from the cells, and the fraction of surviving cells was estimated after illumination of $50 \mathrm{~J} / \mathrm{cm}^{2}$ blue light. From these data, we observed a correlation between the amount of porphyrins produced in the cells and the extent of cell death after blue light treatment (Fig. 5). Interestingly, we observed that the most efficient 5-ALA concentration, i.e. the one that caused the highest porphyrin production, was $0.05 \mathrm{mM}$ of the $S$. aureus Newman strain and $0.1 \mathrm{mM}$ for the $\Delta \mathrm{HrtA}$ strain. When higher concentrations were used, namely $1 \mathrm{mM}$, lower amounts of porphyrins were extracted from the cells. In every case, the 1-mM 5-ALA treatment resulted in reduced mortality after blue light treatment. Figure 5 shows that when endogenous photosensitisers are induced in $S$. aureus cells, the behaviour of the two analysed strains, namely wild-type Newman and the $\Delta$ HrtA mutant, is similar with respect to PDI susceptibility. Moreover, the extent of cell survival reduction correlated well with the amount of porphyrins induced after 5-ALA treatment. The observed reduction in survival of b

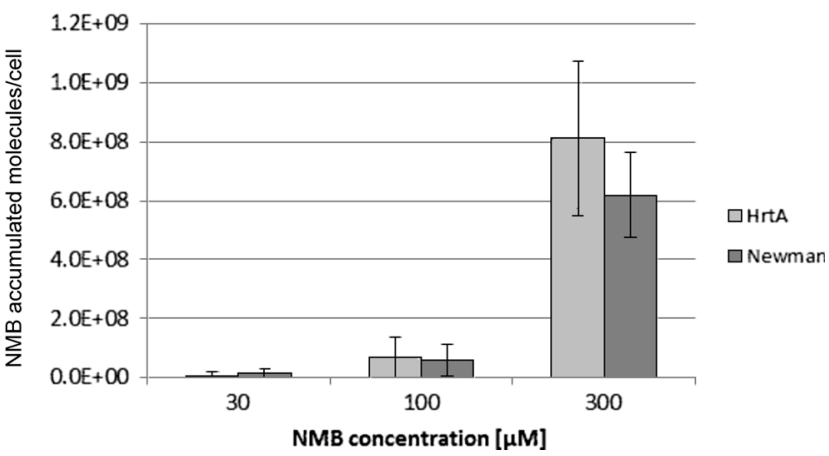

increasing concentrations, as indicated in the picture (PS concentration range of 1-20 $\mu \mathrm{M}$ for PpIX and 10-300 $\mu \mathrm{M}$ for NMB). Cells were incubated with PS at $20{ }^{\circ} \mathrm{C}$ for $30 \mathrm{~min}$. The value of the accumulated PS is represented as the number of molecules per cell

the analysed strains after 5-ALA treatment was in accordance with the results obtained from FACS analyses. Using this technique, the percentage of fluorescing bacterial cells after incubation with 5-ALA was estimated to be similar for these two strains (Table 1). This suggests that HrtA does not play a role in a 5-ALA-based PDI. It must be noted however that we have made rough estimation based on technical repeats. We did not perform statistical analysis on these results.

\section{Trypsin treatment affects PpIX uptake in $\Delta$ HrtA}

There is currently no specific inhibitor available for HrtA transporter; thus, we applied a trypsin treatment approach to analyse the participation of proteins in the process of photosensitizer uptake by bacterial cells. We incubated cells with

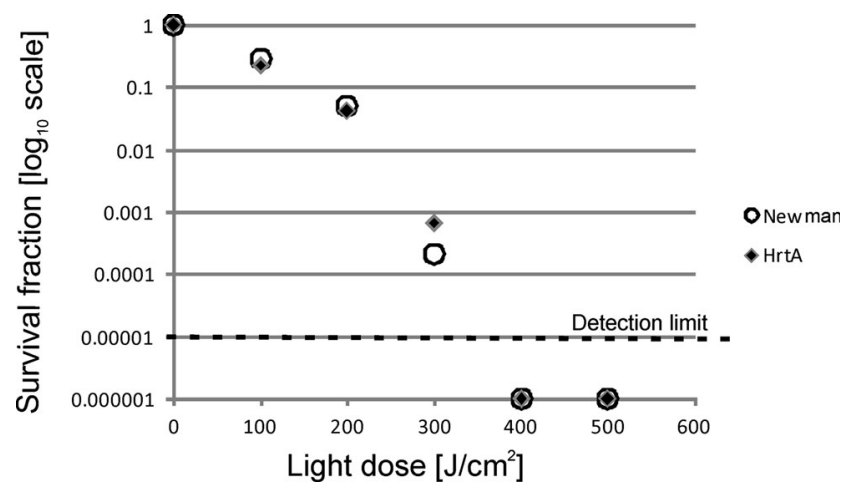

Fig. 4 Light dose-dependent survival of bacterial $S$. aureus cells after photodynamic treatment. Survival of the wild-type $S$. aureus Newman strain and its isogenic $S$. aureus HrtA mutant strain were measured after PDI treatment with respect to increasing light doses. After incubation with $300 \mu \mathrm{M} \mathrm{NMB}$, the analysed strains were subjected to $620-780 \mathrm{~nm}$ narrowband light. Bacterial survival was measured by serially diluting the cells and counting the CFUs plated on agar plates before and after treatment. The survival fraction is expressed as the number of CFU obtained after PDI treatment with respect to the number of CFU of nonlight-treated cells. The names of particular strains are indicated in the legend 


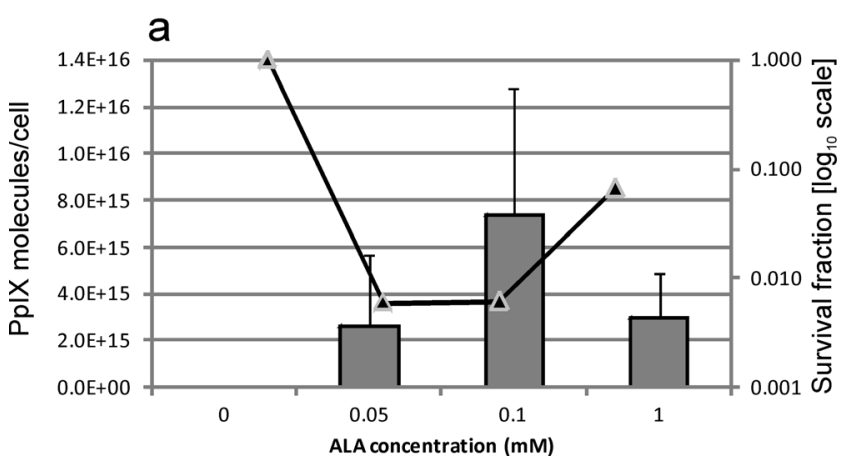

Fig. 5 ALA-induced photodynamic inactivation and intracellular porphyrin content in $S$. aureus. $S$. aureus Newman (a) and its isogenic $\Delta$ HrtA mutant (b) were incubated for $4 \mathrm{~h}$ in the dark with 5-ALA. Bars represent the intracellular bacterial porphyrins (PpIX) produced and extracted from the cells. Solid lines $(\downarrow)$ represent the reduction in

$10 \mu \mathrm{M}$ PpIX in the presence or absence of trypsin. The purpose of trypsin treatment was to 'shave off' cell wall-bound proteins to inactivate them and, therefore, prevent them from affecting PpIX uptake. The cells were incubated with trypsin for $15 \mathrm{~min}$, followed by a 30-min incubation with the photosensitiser. Differences in PpIX uptake could be observed in the trypsin pre-treated cells compared with the non-trypsintreated cells (Fig. 6). In all of the presented experiments, we employed $S$. aureus strain Newman and its three isogenic mutants that were defective in one of the haem transporter systems, namely HrtA, HtsA and IsdD. Although there was an overall trend of a higher PpIX uptake in the control cells (without trypsin addition) compared with the trypsin-treated cells, statistical significance was only found for $\Delta$ HrtA. The highest PpIX uptake value in the control cells was observed for $\triangle \operatorname{HrtA}\left(3.05 \times 10^{10}\right.$ molecules/cell $)$, followed by strain $\Delta \operatorname{IsdD}\left(2.81 \times 10^{10}\right.$ molecules/cell $)$ and the wild-type strain together with $\Delta \mathrm{HtsA}\left(1.93 \times 10^{10}\right.$ and $1.76 \times 10^{10}$ molecules/ cell, respectively). In trypsin-treated strains, the lowest PpIX uptake values were observed for the $\Delta \mathrm{HtsA}$ cells $(1.57 \times$ $10^{10}$ molecules/cell) and the wild-type Newman strain (1.6× $10^{10}$ molecules/cell); slightly higher values were noted for $\Delta \mathrm{HrtA}$ and $\Delta \operatorname{IsdD}\left(1.83 \times 10^{10}\right.$ and $1.93 \times 10^{10} \mathrm{molecules} / \mathrm{cell}$, respectively). Overall, there were no significant differences in the accumulation of PpIX between the studied strains after trypsin treatment. To ensure that trypsin treatment did not affect the cellular conditions, the supernatants of trypsintreated cells were analysed to investigate the possible differences in membrane permeability. We did not observed any differences in the treatment of a particular strain in our experimental conditions (on the Supplementary material Fig. S1).

\section{Cell membranes of Newman and $\Delta$ HrtA strains have various fluidities}

The results of the photoinactivation experiments and the studies on PpIX accumulation did not explain the role of HrtA

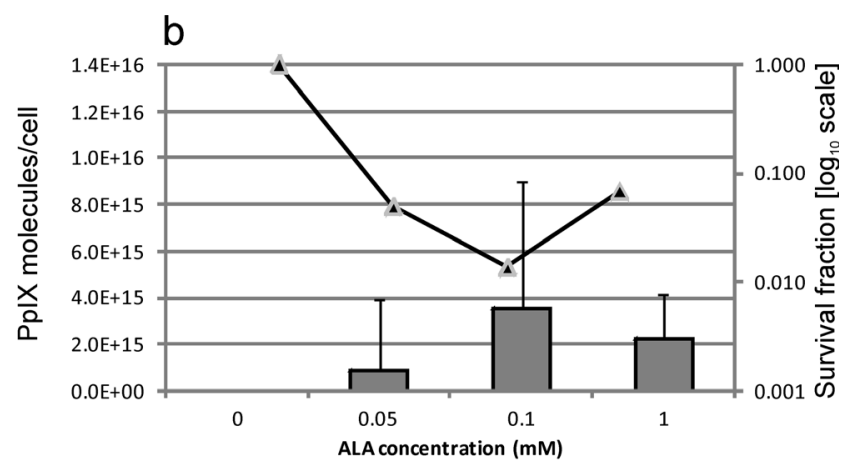

survival after photodynamic treatment with $50 \mathrm{~J} / \mathrm{cm}^{2}$ blue light (385$480 \mathrm{~nm}$ ). Survival fraction is expressed as the number of CFU obtained after PDI treatment with respect to the number of CFU of non-lighttreated cells

transporter in PDI. To explain the phenomenon of increased $\Delta$ HrtA vulnerability to the photoinactivation process when using PpIX, we assessed cell membrane fluidities in both strains. We employed a fluorescent probe to observe the fluidities of the cell membranes in the range of $20-40{ }^{\circ} \mathrm{C}$. The DPH fluorescent probe was used, which provides a strong fluorescent signal in the hydrophobic core of the membrane but lacks fluorescence whilst in an aqueous environment. There is an inverse relationship between fluorescence polarisation values and cell membrane fluidity, which means that the lower polarisation indices, the greater the cell membrane fluidity (Bayer et al. 2000). As can be observed in Fig. 7, the strains differ with respect to their membrane fluidity ( $\triangle \mathrm{HrtA}$ representing the more fluid state of the membrane compared to wild-type Newman). The observed difference was statistically significant at higher temperatures, i.e. $>30^{\circ} \mathrm{C}$.

\section{Differing lipid content in Newman and HrtA strains}

Bacterial membrane fluidity is associated with its lipid composition. Longer acyl chains, increased levels of unsaturation and shifts in iso- to anteiso-branched chain fatty acid content were shown to be associated with higher membrane fluidity (Klein et al. 1999). Following the observation that different fluidity is observed for the $\Delta \mathrm{HrtA}$ mutant compared with a wild-type strain, we employed a mass spectrometry analysis to characterise the lipid profiles of the two analysed strains. We used the methodology described in our previous paper (Hewelt-Belka et al. 2014).

Table 1 Percentage of fluorescing cells after 5-ALA incubation obtained from FACS analysis

\begin{tabular}{lcrrr}
\hline 5-ALA concentration & $0.01 \mathrm{mM}$ & $0.05 \mathrm{mM}$ & $0.1 \mathrm{mM}$ & $1 \mathrm{mM}$ \\
$\begin{array}{l}\text { S. aureus strain } \\
\text { Newman }\end{array}$ & $1.9 \%$ & $11.6 \%$ & $29.4 \%$ & $9.5 \%$ \\
$\Delta \mathrm{HrtA}$ & $0.8 \%$ & $6.8 \%$ & $26.6 \%$ & $19.8 \%$ \\
\hline
\end{tabular}




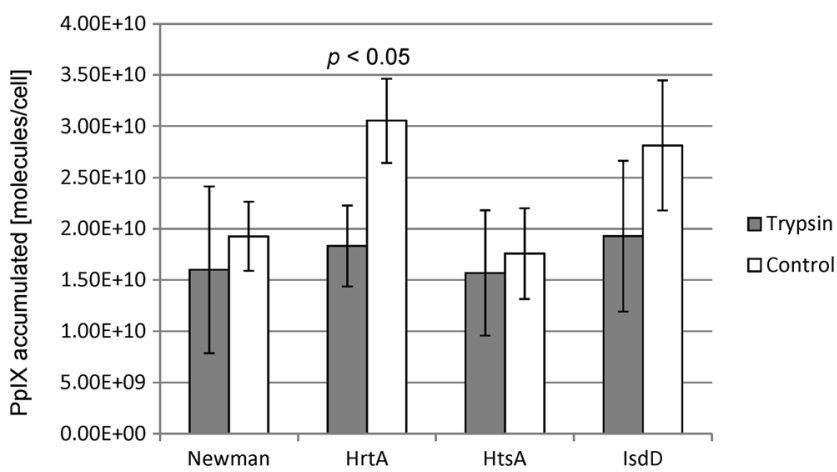

Fig. 6 Trypsin treatment decreases protoporphyrin IX uptake. Uptake of PpIX was carried out in the presence of $10 \mu \mathrm{M}$ of the photosensitiser. In the trypsin-treated cells (trypsin), the samples were incubated with $0.005 \%(w / v)$ trypsin for $15 \mathrm{~min}, 37^{\circ} \mathrm{C}$; washed with PBS buffer; and further incubated with $\mathrm{PpIX}\left(30 \mathrm{~min}, 37^{\circ} \mathrm{C}\right.$ ). In the non-treated samples (control), bacterial cells were incubated directly with PpIX without trypsin pre-treatment. $S$. aureus strains used in the experiments are listed in the legend

We identified all of the main components of lipids present in cell membranes, namely phosphatidylglycerols (PGs), lysylphosphatidylglycerols (Lys-PGs), cardiolipins (CLs), diglycosyldiacylglycerols (DGDGs) and diacylglycerols (DGs). Identification was performed based on an automatic selfprepared database search and a manual investigation of acquired MS/MS spectra according to the previously described methodology (Hewelt-Belka et al. 2014). Interestingly, comparative lipidomics of two analysed strains revealed differences in lipid profiles of the two strains. The identified lipids, which differed significantly between the two strains, are shown in Table 2 . We observed that DGs are present in the $\Delta$ HrtA strain at higher amounts compared with the Newman strain. However, the level of Lys-PGs is significantly higher in the wild-type Newman

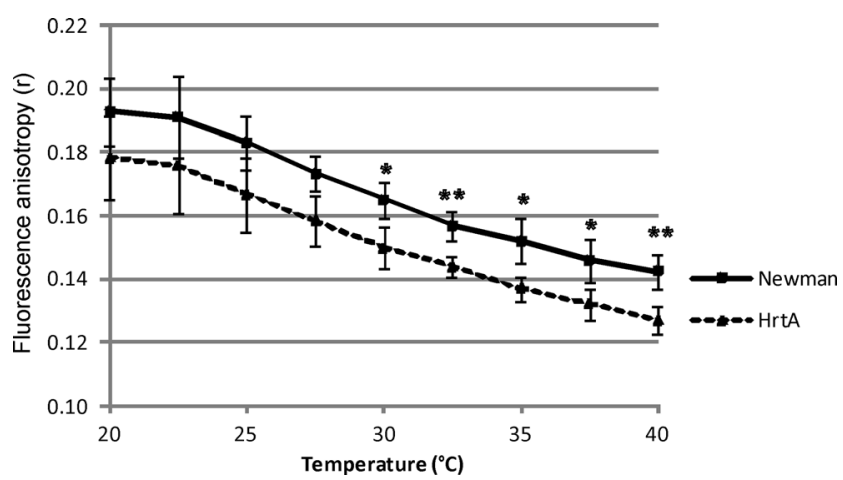

Fig. 7 Cell membrane fluidity. The protoplasts of S. aureus Newman and its isogenic $\Delta H r t A$ mutant were incubated with the 1,6-diphenyl-1,3,5hexatriene (DPH) probe, and fluorescence anisotropy $(r)$ was measured, which inversely correlates with membrane fluidity. The values of fluorescence anisotropy were calculated based on fluorescence intensity measured with a vertical and perpendicular orientation of the analyser according to the equation described in the "Materials and methods" section. The names of particular strains are indicated in the legend. The presented values are the means of at least three biological replicates. *Statistically significant at the level of $<0.05$. **Statistically significant at the level of $<0.01$ strain. An ambiguous pattern was observed for glycosyl diacylglycerols (DGDG) and monoglycosyldiacylglycerol (MGDG) (Table 2).

\section{Discussion}

Iron uptake by bacteria is crucial for survival and pathogenicity. In humans, haem is the most abundant iron source. Bacteria use highly specific haem transport systems to capture it and transport it into the cell for utilisation. Bacteria have evolved several systems that enable efficient haem-iron transport. Some authors have proposed that protoporphyrin IX, which is structurally similar to a haem molecule, may be a substrate for the haem transport machinery (Moriwaki et al. 2011). In terms of photodynamic inactivation, this suggests that the response of bacteria to PDI may depend on specific proteins; thus, resistance may occur whilst treating the cells with a combination of sublethal doses of light and a photosensitiser. We hypothesised that haem transporters may participate in the process of photosensitiser accumulation to further influence the outcome of PDI.

The accumulation of a photosensitiser is a pre-requisite of photodynamic inactivation. The mechanism of porphyrin photosensitiser accumulation has primarily been studied with respect to eukaryotic cells, in which hydrophobic porphyrin photosensitisers mainly accumulated in the membrane fraction and caused severe damage following illumination compared with hydrophilic porphyrin photosensitisers (Sandberg and Romslo 1980). When we consider bacterial cells to be targets for photodynamic action, negatively charged porphyrins do not appear to be very effective because they easily aggregate in water solutions and are electrostatically repulsed by the negatively charged membrane. Here, we chose PpIX as a photosensitiser for our analysis because it is naturally produced by bacteria and it is the closest structural analogue of haem.

The decrease in PpIX accumulation after trypsin treatment was the highest for the $\Delta$ HrtA mutant, which may indicate a particular role of this phenotype in the photodynamic inactivation of $S$. aureus. We were interested in verifying our initial hypothesis that PpIX is a substrate for the HrtAB export system. Consequently, the inactivation of HrtA results in the accumulation of a higher amount of PpIX photosensitiser in the cells and thus in higher efficacy in PDI outcome. In the case of non-trypsin-treated $\Delta$ HrtA cells, the accumulation of the PS correlated well with the PDI response and the $\Delta$ HrtA strain was killed most efficiently in the PpIX-based PDI, both in a PpIX concentration-dependent manner as well as a light dosedependent manner (Figs. 1 and 2). The lack of a specific inhibitor of the HrtAB transporting system precludes definite conclusions from these observations. Nevertheless, decreased accumulation of PpIX after trypsin treatment was only observed for the $\Delta$ HrtA mutant. The highest PPIX uptake was 
Table 2 Identification of lipid groups differing $S$. aureus Newman and $\Delta$ HrtA strains

\begin{tabular}{|c|c|c|c|c|c|}
\hline Lipid group & Retention time (min) & Neutral mass & Ion & $\Delta$ HrtA/Newman (fold change) & $p$ test $U$ \\
\hline DG (15:0/15:0) & 14.5596 & 562.4578 & {$[\mathrm{M}+\mathrm{Na}]^{+}$} & 1.338038 & 0.008658 \\
\hline DG $(15: 0 / 17: 0)$ & 17.07775 & 590.4893 & {$[\mathrm{M}+\mathrm{Na}]^{+}$} & 1.247986 & 0.008658 \\
\hline DG (15:0/19:0) & 18.9791 & 618.5205 & {$[\mathrm{M}+\mathrm{Na}]^{+}$} & 1.300394 & 0.008658 \\
\hline Lys-PG (15:0/18:0) & 14.70278 & 864.6213 & {$[\mathrm{M}+\mathrm{H}]^{+}$} & 0.618535 & 0.002165 \\
\hline Lys-PG (15:0/19:0) & 15.91993 & 878.6369 & {$[\mathrm{M}+\mathrm{H}]^{+}$} & 0.57844 & 0.002165 \\
\hline Lys-PG (15:0/20:0) & 16.95452 & 892.6527 & {$[\mathrm{M}+\mathrm{H}]^{+}$} & 0.622163 & 0.002165 \\
\hline DGDG (15:0/15:0) & 10.55135 & 881.6081 & {$\left[\mathrm{M}+\mathrm{NH}_{4}\right]^{+}$} & 1.38726 & 0.002165 \\
\hline DGDG $(15: 0 / 17: 0)$ & 16.3492 & 909.6397 & {$\left[\mathrm{M}+\mathrm{NH}_{4}\right]^{+}$} & 1.289001 & 0.002165 \\
\hline DGDG (15:0/17:0) & 11.43655 & 909.6376 & {$\left[\mathrm{M}+\mathrm{NH}_{4}\right]^{+}$} & 0.861046 & 0.015152 \\
\hline DGDG (15:0/18:0) & 13.44875 & 923.6556 & {$\left[\mathrm{M}+\mathrm{NH}_{4}\right]^{+}$} & 0.792507 & 0.008658 \\
\hline DGDG (15:0/19:0) & 14.42605 & 937.671 & {$\left[\mathrm{M}+\mathrm{NH}_{4}\right]^{+}$} & 1.186194 & 0.002165 \\
\hline DGDG (15:0/19:0) & 14.84777 & 937.6709 & {$\left[\mathrm{M}+\mathrm{NH}_{4}\right]^{+}$} & 0.698586 & 0.008658 \\
\hline DGDG (15:0/20:0) & 15.9671 & 951.687 & {$\left[\mathrm{M}+\mathrm{NH}_{4}\right]^{+}$} & 1.186194 & 0.004329 \\
\hline DGDG (17:0/20:0) & 17.68063 & 979.7174 & {$\left[\mathrm{M}+\mathrm{NH}_{4}\right]^{+}$} & 0.718813 & 0.002165 \\
\hline MGDG (15:0/17:0) & 14.21557 & 747.5866 & {$\left[\mathrm{M}+\mathrm{NH}_{4}\right]^{+}$} & 1.246444 & 0.002165 \\
\hline MGDG (15:0/18:0) & 15.90033 & 761.6022 & {$\left[\mathrm{M}+\mathrm{NH}_{4}\right]^{+}$} & 0.817235 & 0.015152 \\
\hline MGDG (15:0/19:0) & 16.59992 & 775.6177 & {$\left[\mathrm{M}+\mathrm{NH}_{4}\right]^{+}$} & 1.278867 & 0.008658 \\
\hline MGDG (15:0/20:0) & 17.81935 & 789.6335 & {$\left[\mathrm{M}+\mathrm{NH}_{4}\right]^{+}$} & 0.834633 & 0.004329 \\
\hline
\end{tabular}

$D G s$ diacylglycerols, Lys- $P G$ s lysyl-phosphatidylglycerols, $D G D G$ s diglycosyldiacylglycerols, $M G D G s$ monoglycosyldiacylglycerols

detected for the HrtA mutant strain. However, upon trypsin treatment, PpIX uptake was lower and similar for all the strains tested. If the function of HrtA is responsible for the observed PpIX uptake difference (trypsin treatment vs. no trypsin), then we would observe it in the wild-type Newman strain and not in the mutant, in which HrtA is innately absent. This indicates that the lack of a physical presence of the HrtA protein in the membrane (and not its function) is responsible for higher accumulation of PpIX, in addition to the higher efficacy of photoinactivation. Recent studies by Wakeman et al. (2014) showed that HrtAB was not capable of exporting toxic and non-toxic metalloporphyrins from $S$. aureus cells; however, PpIX itself was not studied. PS accumulation is known to lead to efficient PDI, but it is not always obvious that higher amounts of PS accumulation result in more effective PDI. For example, S. aureus and Staphylococcus epidermidis strains that produced biofilms were shown to accumulate more PS than their mutated (not producing biofilm) counterparts but were killed less efficiently with the use of chlorine(e6) as a PS (Gad et al. 2004). The charge and structure of the slime may induce PS trapping, thereby preventing it from reaching its effective destination (e.g. the membrane). This is likely not the case in our research, because all the studied strains are of the same genetic background and differ only according to the presence of particular haem transporters. However, based on the data from literature, the net charge and the structure of the bacterial cell surface may be disturbed when deleting membrane or cell surface proteins. This is exemplified by the observation that HrtB expression compromises the membrane structure in $S$. aureus strains that lack HrtA (Attia et al. 2010). The exposure of $\Delta$ HrtA to haem was demonstrated to affect the membrane structure but leave the cells viable.

There are several explanations for why $\Delta \mathrm{HrtA}$ is the most susceptible strain to porphyrin-mediated PDI. One explanation may be related to the perturbations in a membrane, whereas others can be associated with an increase in protein content on the cell surface. When the $\Delta$ HrtA strain was challenged with haem, over 500 transcripts were shown to be upregulated, including several proteins that are associated with the cell wall, such as sortase A, fibronectin and fibrinogen-binding protein (more than 30-fold increase) (Stauff et al. 2008). Such proteins can represent an anchor for PpIX by trapping the photosensitiser near its site of action and further enabling efficient photokilling. However, the amount of PpIX accumulated by $\Delta \mathrm{HrtA}$ after trypsin treatment was decreased compared with that in non-treated cells. In the remaining strains, including wild-type Newman, the PpIX accumulation level was unchanged (Fig. 6). Protoporphyrin IX was shown to interact with proteins such as human albumin and highdensity lipoprotein (Kowalska et al. 2003). Porphyrinmediated binding to haemoglobin and haemagglutinins was also demonstrated (Decarlo et al. 1999). However, in our experimental conditions, the roles of surface proteins in PpIX accumulation were minor. The second explanation for the higher susceptibility of the $\Delta \mathrm{HrtA}$ mutant to PpIX may be associated with the properties of the bacterial membrane and a lack of HrtA protein. We observed differences in fluidity of 
the membrane of the two analysed strains. Additionally, the lipid content, which affects many cellular processes, varied between the two analysed strains. A lack of DGDG increased sensitivity to high light stress in Synechocystis (Mizusawa et al. 2009). and DGDG assists in protein-protein interactions in membranes (Domonkos et al. 2008). Potential differences in the glycosyl diacylglycerols (DGDG and MGDG) content in the analysed strains were ambiguous (Table 2). This precluded thorough interpretation of the results. However, the other two groups of lipids, namely DGs and Lys-PGs, showed a specific distribution pattern, the first one being overrepresented in the $\Delta$ HrtA mutant and the latter being more abundant in the wild-type Newman strain. The modification of the PG headgroup with lysine modulates the charge of the cytoplasmic membrane. PG lysinylation was shown to be correlated with reduced susceptibility of $S$. aureus to some antibiotics and cationic antimicrobial peptides due to increased positive charges of the membrane (Jones et al. 2008; Nishi et al. 2004; Peschel et al. 2001). Further detailed analysis on the model membrane system revealed a role of Lys-PG in the stabilisation of the membrane rather than the prevention of cationic antimicrobial binding (Kilelee et al. 2010). This is in accordance with our results in which the $\Delta \mathrm{HrtA}$ mutant possessed significantly less Lys-PG and thus a less stable membrane than the Newman strain, which led to increased susceptibility to PDI and increased PpIX accumulation.

In the first part of our experimental work in which exogenous PpIX was used as a photosensitiser, we observed $\Delta \mathrm{HrtA}$ to be the most vulnerable to PDI treatment. However, this was not the case when bacterial cells were incubated with 5-ALA, which induced the production of intracellular porphyrins (Nitzan and Kauffman 1999). The analysed transporter mutants expressed a pattern of PDI response very similar to that in the wild-type Newman strain when treated with 5-ALA (Fig. 5). Similar to previously published data (Lipovsky et al. 2009). we observed a relationship between the intracellular porphyrin content and the ALA-based PDI outcome in the strains presented in our paper. Notably, this phenomenon was not dependent on the presence or absence of the HrtA protein. Flow cytometry-based analyses conducted by us for the two analysed strains revealed that the percentage of fluorescing cells in each analysed strain was similar (Table 1), thereby confirming the previous data.

The most important conclusion based on the obtained results is that the haem transporter element, namely HrtA, is involved in the photodynamic inactivation of $S$. aureus cells with PpIX. The observed phenomenon is related to the high PpIX accumulation in $h r t A$-deleted cells, which further corresponds to an effective PDI outcome. We cannot exclude the possibility that PpIX is a substrate for the HrtAB efflux pump, which exports membrane-localised PpIX and therefore plays an important role in the $S$. aureus response to PpIX-based photodynamic inactivation. However, we also observed that a lack of the HrtA subunit alters bacterial cell membrane composition and fluidity, which sensitises $S$. aureus to photodynamic treatment. Our results highlight the role of the physical properties of the membrane as a molecular target for PpIX in photodynamic inactivation. It will be of interest to determine whether the physical properties of the membrane are also important for interactions between other photosensitisers and the cellular membrane.

Acknowledgments This work was supported by National Science Centre Poland grant no. 2013/09/B/NZ7/00410 and grant no. 2014/13/N/ ST4/03899. The study sponsor had no involvement in the study design, collection, analysis or interpretation of data. The authors wish to thank Dr. Eric P. Skaar from the Department of Microbiology and Immunology at Vanderbilt University Medical Center for kindly providing the $S$. aureus strains. Great technical support with FACS analyses by Dr. Andrea Lipinska (Department of Molecular Virology, Intercollegiate Faculty of Biotechnology, University of Gdansk and Medical University of Gdansk) is acknowledged.

Authors' contributions JN conceived the study, carried out the experimental work, analysed the results and drafted the manuscript. MK-Z performed the experiments and analysed the results. MF carried out the experiments and drafted the manuscript. WH-B performed the experiments. MG provided the technical support and helped draft the manuscript. KPB edited and drafted the manuscript. All authors read and approved the final manuscript.

\section{Compliance with ethical standards}

Conflict of interest The authors declare that they have no conflict of interest.

Open Access This article is distributed under the terms of the Creative Commons Attribution 4.0 International License (http:// creativecommons.org/licenses/by/4.0/), which permits unrestricted use, distribution, and reproduction in any medium, provided you give appropriate credit to the original author(s) and the source, provide a link to the Creative Commons license, and indicate if changes were made.

\section{References}

Almeida J, Tome JP, Neves MG, Tome AC, Cavaleiro JA, Cunha A, Costa L, Faustino MA, Almeida A (2014) Photodynamic inactivation of multidrug-resistant bacteria in hospital wastewaters: influence of residual antibiotics. Photochem Photobiol Sci 13:626-633

Attia AS, Benson MA, Stauff DL, Torres VJ, Skaar EP (2010) Membrane damage elicits an immunomodulatory program in Staphylococcus aureus. PLoS Pathog 6:e1000802

Bayer AS, Prasad R, Chandra J, Koul A, Smriti M, Varma A, Skurray RA, Firth N, Brown MH, Koo SP, Yeaman MR (2000) In vitro resistance of Staphylococcus aureus to thrombin-induced platelet microbicidal protein is associated with alterations in cytoplasmic membrane fluidity. Infect Immun 68:3548-3553

Beasley FC, Vines ED, Grigg JC, Zheng Q, Liu S, Lajoie GA, Murphy ME, Heinrichs DE (2009) Characterization of staphyloferrin A biosynthetic and transport mutants in Staphylococcus aureus. Mol Microbiol 72:947-963 
Bligh EG, Dyer WJ (1959) A rapid method of total lipid extraction and purification. Can J Biochem Physiol 37:911-917

Decarlo AA, Paramaesvaran M, Yun PL, Collyer C, Hunter N (1999) Porphyrin-mediated binding to hemoglobin by the HA2 domain of cysteine proteinases (gingipains) and hemagglutinins from the periodontal pathogen Porphyromonas gingivalis. J Bacteriol 181:3784 3791

Domonkos I, Laczko-Dobos H, Gombos Z (2008) Lipid-assisted proteinprotein interactions that support photosynthetic and other cellular activities. Prog Lipid Res 47:422-435

Duthie ES, Lorenz LL (1952) Staphylococcal coagulase; mode of action and antigenicity. J Gen Microbiol 6:95-107

Friedman DB, Stauff DL, Pishchany G, Whitwell CW, Torres VJ, Skaar EP (2006) Staphylococcus aureus redirects central metabolism to increase iron availability. PLoS Pathog 2:e87

Gad F, Zahra T, Hasan T, Hamblin MR (2004) Effects of growth phase and extracellular slime on photodynamic inactivation of Grampositive pathogenic bacteria. Antimicrob Agents Chemother 48: 2173-2178

Giuliani F, Martinelli M, Cocchi A, Arbia D, Fantetti L, Roncucci G (2010) In vitro resistance selection studies of RLP068/Cl, a new $\mathrm{Zn}$ (II) phthalocyanine suitable for antimicrobial photodynamic therapy. Antimicrob Agents Chemother 54:637-642

Grinholc M, Szramka B, Kurlenda J, Graczyk A, Bielawski KP (2008) Bactericidal effect of photodynamic inactivation against methicillinresistant and methicillin-susceptible Staphylococcus aureus is strain-dependent. J Photochem Photobiol B 90:57-63

Hewelt-Belka W, Nakonieczna J, Belka M, Baczek T, Namiesnik J, KotWasik A (2014) Comprehensive methodology for Staphylococcus aureus lipidomics by liquid chromatography and quadrupole timeof-flight mass spectrometry. J Chromatogr A 1362:62-74

Jones T, Yeaman MR, Sakoulas G, Yang SJ, Proctor RA, Sahl HG, Schrenzel J, Xiong YQ, Bayer AS (2008) Failures in clinical treatment of Staphylococcus aureus Infection with daptomycin are associated with alterations in surface charge, membrane phospholipid asymmetry, and drug binding. Antimicrob Agents Chemother 52: 269-278

Kennedy JC, Pottier RH (1992) Endogenous protoporphyrin IX, a clinically useful photosensitizer for photodynamic therapy. J Photochem Photobiol B 14:275-292

Kilelee E, Pokorny A, Yeaman MR, Bayer AS (2010) Lysylphosphatidylglycerol attenuates membrane perturbation rather than surface association of the cationic antimicrobial peptide 6W-RP-1 in a model membrane system: implications for daptomycin resistance. Antimicrob Agents Chemother 54:4476-4479

Klein W, Weber MH, Marahiel MA (1999) Cold shock response of Bacillus subtilis: isoleucine-dependent switch in the fatty acid branching pattern for membrane adaptation to low temperatures. J Bacteriol 181:5341-5349

Kowalska A, Kwiek P, Milosz E, Gondek G, Romiszewska A, Graczyk A, Podhajska AJ (2003) Application of electrophoretic methods for detection of protein-porphyrin complexes. Acta Biochim Pol 50: $1155-1163$

Lipovsky A, Nitzan Y, Friedmann H, Lubart R (2009) Sensitivity of Staphylococcus aureus strains to broadband visible light. Photochem Photobiol 85:255-260

Mack J, Vermeiren C, Heinrichs DE, Stillman MJ (2004) In vivo heme scavenging by Staphylococcus aureus IsdC and IsdE proteins. Biochem Biophys Res Commun 320:781-788

Maisch T, Bosl C, Szeimies RM, Love B, Abels C (2007) Determination of the antibacterial efficacy of a new porphyrin-based photosensitizer against MRSA ex vivo. Photochem Photobiol Sci 6:545-551

Mason WJ, Skaar EP (2009) Assessing the contribution of heme-iron acquisition to Staphylococcus aureus pneumonia using computed tomography. PLoS ONE 4:e6668
Mazmanian SK, Skaar EP, Gaspar AH, Humayun M, Gornicki P, Jelenska J, Joachmiak A, Missiakas DM, Schneewind O (2003) Passage of heme-iron across the envelope of Staphylococcus aureus. Science 299:906-909

Merchat M, Bertolini G, Giacomini P, Villanueva A, Jori G (1996) Mesosubstituted cationic porphyrins as efficient photosensitizers of Gram-positive and Gram-negative bacteria. J Photochem Photobiol B 32:153-157

Mizusawa N, Sakurai I, Sato N, Wada H (2009) Lack of digalactosyldiacylglycerol increases the sensitivity of Synechocystis sp. PCC 6803 to highlight stress. FEBS Lett 583: 718-722

Moriwaki Y, Caaveiro JM, Tanaka Y, Tsutsumi H, Hamachi I, Tsumoto K (2011) Molecular basis of recognition of antibacterial porphyrins by heme-transporter IsdH-NEAT3 of Staphylococcus aureus. Biochemistry 50:7311-7320

Nakonieczna J, Michta E, Rybicka M, Grinholc M, Gwizdek-Wisniewska A, Bielawski KP (2010) Superoxide dismutase is upregulated in Staphylococcus aureus following protoporphyrin-mediated photodynamic inactivation and does not directly influence the response to photodynamic treatment. BMC Microbiol 10:323

Nishi H, Komatsuzawa H, Fujiwara T, McCallum N, Sugai M (2004) Reduced content of lysyl-phosphatidylglycerol in the cytoplasmic membrane affects susceptibility to moenomycin, as well as vancomycin, gentamicin, and antimicrobial peptides, in Staphylococcus aureus. Antimicrob Agents Chemother 48:4800-4807

Nitzan Y, Kauffman M (1999) Endogenous porphyrin production in bacteria by delta-aminolaevulinic acid and subsequent bacterial photoeradication. Lasers Med Sci 14:269-277

Ochsner M (1997) Photophysical and photobiological processes in the photodynamic therapy of tumours. J Photochem Photobiol B 39:1-18

Ooi N, Miller K, Hobbs J, Rhys-Williams W, Love W, Chopra I (2009) XF-73, a novel antistaphylococcal membrane-active agent with rapid bactericidal activity. J Antimicrob Chemother 64:735-740

Oriel S, Nitzan Y (2012) Mechanistic aspects of photoinactivation of Candida albicans by exogenous porphyrins. Photochem Photobiol 88:604-612

Peschel A, Jack RW, Otto M, Collins LV, Staubitz P, Nicholson G, Kalbacher H, Nieuwenhuizen WF, Jung G, Tarkowski A, van Kessel KP, van Strijp JA (2001) Staphylococcus aureus resistance to human defensins and evasion of neutrophil killing via the novel virulence factor $\mathrm{MprF}$ is based on modification of membrane lipids with 1-lysine. J Exp Med 193:1067-1076

Prout GR Jr, Lin CW, Benson R Jr, Nseyo UO, Daly JJ, Griffin PP, Kinsey J, Tian ME, Lao YH, Mian YZ (1987) Photodynamic therapy with hematoporphyrin derivative in the treatment of superficial transitional-cell carcinoma of the bladder. N Engl J Med 317:1251-1255

Sandberg S, Romslo I (1980) Porphyrin-sensitized photodynamic damage of isolated rat liver mitochondria. Biochim Biophys Acta 593: $187-195$

Schastak S, Ziganshyna S, Gitter B, Wiedemann P, Claudepierre T (2010) Efficient photodynamic therapy against Gram-positive and Gramnegative bacteria using THPTS, a cationic photosensitizer excited by infrared wavelength. PLoS ONE 5:e11674

Skaar EP, Humayun M, Bae T, DeBord KL, Schneewind O (2004) Ironsource preference of Staphylococcus aureus infections. Science 305: $1626-1628$

Stauff DL, Torres VJ, Skaar EP (2007) Signaling and DNA-binding activities of the Staphylococcus aureus HssR-HssS two-component system required for heme sensing. J Biol Chem 282:26111-26121

Stauff DL, Bagaley D, Torres VJ, Joyce R, Anderson KL, Kuechenmeister L, Dunman PM, Skaar EP (2008) Staphylococcus aureus HrtA is an ATPase required for protection against heme toxicity and prevention of a transcriptional heme stress response. $\mathrm{J}$ Bacteriol 190:3588-3596 
Tavares A, Carvalho CM, Faustino MA, Neves MG, Tome JP, Tome AC, Cavaleiro JA, Cunha A, Gomes NC, Alves E, Almeida A (2010) Antimicrobial photodynamic therapy: study of bacterial recovery viability and potential development of resistance after treatment. Mar Drugs 8:91-105

Torres VJ, Stauff DL, Pishchany G, Bezbradica JS, Gordy LE, Iturregui J, Anderson KL, Dunman PM, Joyce S, Skaar EP (2007) A Staphylococcus aureus regulatory system that responds to host heme and modulates virulence. Cell Host Microbe 1:109-119

Tortik N, Spaeth A, Plaetzer K (2014) Photodynamic decontamination of foodstuff from Staphylococcus aureus based on novel formulations of curcumin. Photochem Photobiol Sci 13:1402-1409

Voss D, Montville TJ (2014) 1,6-Diphenyl-1,3,5-hexatrine as a reporter of inner spore membrane fluidity in Bacillus subtilis and Alicyclobacillus acidoterrestris. J Microbiol Methods 96:101-103

Wakeman CA, Stauff DL, Zhang Y, Skaar EP (2014) Differential activation of Staphylococcus aureus heme detoxification machinery by heme analogues. J Bacteriol 196:1335-1342

Wilson M, Burns T, Pratten J, Pearson GJ (1995) Bacteria in supragingival plaque samples can be killed by low-power laser light in the presence of a photosensitizer. J Appl Bacteriol 78:569-574 